\title{
Strategi Memasarkan Kesenian Betawi Gambang Kromong Berbasis Augmented Reality
}

\author{
Dwi Mandasari Rahayu, Shifa Rafida Fitri
}

Politeknik Negeri Media Kreatif, Jl. Srengseng Sawah, Jagakarsa, Jakarta Selatan 12640 Politeknik Negeri Media Kreatif, Jl. Srengseng Sawah, Jagakarsa, Jakarta Selatan 12640

\section{INFORMASI ARTIKEL}

Sejarah Artikel:

Diterima Redaksi: 04 September 20

Revisi Akhir: 30 November 20

Diterbitkan Online: 15 Desember 20

\section{KATA KUNCI \\ Pemasaran Gambang Kromong \\ Augmented Reality \\ Booket}

KORESPONDENSI

mandasari@polimedia.ac.id

shifa.rf@gmail

\section{PENDAHULUAN}

Ibu kota Jakarta saat ini tumbuh dan berkembang menjadi kota metropolitan yang terdiri dari beragam suku. Terdapat ratusan suku berbeda dari seluruh wilayah di Indonesia. Suku asli Jakarta yaitu suku Betawi yang berkembang pada masa kolonial. Budaya Betawi juga menjadi maskot pembangunan di Jakarta sampai saat ini (Suswandari, 2016).

Banyaknya pendatang di Jakarta dari berbagai daerah dan negara mengakibatkan terjadinya akulturasi budaya yaitu kebudayaan asing yang lambat laun diterima dan diolah ke dalam kebudayaannya sendiri tanpa menghilangkan unsur kebudayaan dari kelompok itu sendiri. Hal ini mengakibatkan Budaya Betawi dipengaruhi oleh budaya Jawa, Bali, Bugis, Cina, Arab, dan Eropa. Sebagai contoh bentuk pengaruh yang dipertahankan terdapat pada kesenian topeng, lenong, tanjidor, serta gambang kromong (Ariesta, 2016).

Gambang Kromong merupakan salah satu hasil akulturasi seni dan budaya Tiongkok. Alat musik yang digunakan adalah rebab Tiongkok, sam hian, gendang hingga boning lima. Lagu-lagu yang dimainkan umumnya bersifat gembira, jenaka maupun bermakna sindiran dengan tangga lagu pentatonis. Contoh beberapa lagu yang dimainkan yaitu : Centeh, Manis Berdiri, Mas Nona, Gula Ganting, Jali-jali dan Akang Haji (Riyanto, 2017).

Kesadaran akan pelestarian suatu budaya tercantum pada Pasal 32 ayat (1) UUD NRI 1945 yang berbunyi "Negara memajukan kebudayaan nasional Indonesia di tengah peradaban dunia dengan menjamin kebebasan masyarakat dalam memelihara dan mengembangkan nilai-nilai budayanya".

Permasalahan saat ini yaitu suku Betawi mengalami pergeseran menjadi suku yang minoritas. Banyak kebudayaan dan kesenian Betawi yang semakin terkikis di era serba maju. Perlu adanya pemasaran terhadap kesenian dan kebudayaan betawi agar masyarakat bisa menjaga kelestarian budaya tersebut sehingga tidak punah.

Pemasaran merupakan proses sosial dan manajerial di dalamnya terdapat individu dan kelompok untuk mendapatkan hal-hal yang mereka butuhkan dan inginkan dengan menciptkan, menawarkan secara bebas mempertukarkan produk yang bernilai dengan pihak lain (Kotler dan Amstrong, 2012). Menurut Kotler dan Keller (2012) bahwa pemasaran adalah proses identifikasi dan proses untuk dapat memenuhi kebutuhan manusia serta kebutuhan sosial serta ditemukan keuntungan didalamnya. 
Cara memasarkan kesenian Gambang Kromong kepada masyarakat luas yaitu dengan cara memanfaatkan teknologi saat ini. Maka peneliti memiliki ide untuk menggunakan aplikasi Augmented Reality. Menurut Mealy (2018), Augmented Reality yaitu cara melihat dunia nyata secara langsung atau melalui perangkat seperti kamera yang menciptakan suatu penglihatan dari dunia nyata dengan "menambah" objek yang dihasilkan komputer seperti: grafis, audio, atau video ke dalamnya secara langsung.

Penggunaan Augmented Reality sangat banyak kita temukan pada bidang hiburan dan juga industri game seperti Pokemon Go, Father IO Jurassic Alive, Ghostbuster World, dan Harry Potter: Wizards Unite, di masa depan nanti hampir semua bidang akan menggunakan Augmented Reality sebagai alat bantu ataupun peraga virtual yang akan memudahkan pekerjaan manusia (Feiner, 2011). Bidang pendidikan saat ini juga sudah memanfaatkan aplikasi Augmented Reality pada pelajaran biologi atau sains untuk menjelaskan Anatomy 4D, Science AR, Element 4D. Hal ini dikarenakan aplikasi Augmented Reality membantu para siswa untuk lebih mudah memahami serta meningkatkan fleksibilitas belajar (Farlex 2014). Penelitian ini mengacu penelitian sebelumnya yang sudah dilakukan oleh (Gama, 2019) dan Yustafa (2015).

Berdasarkan latar belakang dan masalah tersebut, maka penulis ingin membantu memberikan solusi dengan cara memasarkan kesenian Gambang Kromong dengam menggunakan aplikasi Augmented Reality. Hal ini merupakan sebuah inovasi dijaman teknologi yang serba maju yaitu dengan membuat sebuah booklet yang berisikan informasi mengenai Gambang Kromong berbasis Augmented Reality menggunakan virtual button.

Tujuan penelitian ini yaitu memasarkan kesenian Gambang Kromong kepada masyarakat dengan membuat sebuah booklet pada aplikasi Augmented Reality menggunakan virtual button untuk memberikan informasi kepada masyarakat agar dapat meningkatkan kesadaran masyarakat terhadap kesenian Gambang Kromong serta melestarikan kesenian dan kebudayaan Betawi.

Adapun identifikasi masalah dalam penelitian ini yaitu:

1. Kesenian Betawi yang terkikis oleh perubahan dan para pendatang

2. Perlu adanya strategi untuk memperkenalkan dan melestarikan budaya Betawi.

\section{TINJAUAN PUSTAKA}

\subsection{Augmented Reality}

Augmented Reality merupakan sebuah cara lain dalam memandang dunia nyata secara langsung maupun menggunakan kamera yang membuat sebuah visual di dalam dunia nyata, dan "menambah" objek yang dihasilkan komputer seperti grafis, audio, dan video. Augmented Reality memiliki perbedaan dengan Virtual Reality dalam penambahan objeknya. Augmented Reality menambahkan objek ke dalam dunia nyata atau pemandangan yang ada dibanding membuat goresan suatu hal baru. Hal terbesar yang ada pada Augmented Reality adalah kemampuannya dalam menempatkan sebuah objek maya kedalam 3 Dimensional, dan ruangan dunia nyata (Mealy, 2018).

Objek yang digunakan dalam Augmented Reality dapat berupa teks, animasi, 3D model ataupun video yang dipadukan dengan lingkungan nyata, sehingga pengguna dapat merasakan objek maya secara langsung disekitar mereka. Augmented Reality digunakan dalam berbagai bidang, salah satunya adalah militer dan periklanan. Dan saat ini mulai merambat pada bidang edukasi.

Marker-based dalam sistem Augmented Reality menggunakan simbol gambar fisik dunia sebagai nilai referensi untuk dilapisi dengan hasil komputer. Dalam sistem ini, kamera terus berlanjut mengambil gambar dari objek yang di target dan memproses perkiraan posisi, orientasi, dan gerak dari visual yang ditampilkan agar selaras dengan target objek. Sebagai contoh, sebuah marker 2D yang sudah dicetak lalu diletakkan didepan sebuah web kamera. Komputer akan mengartikan simbol yang terdapat pada kertas ke dalam layar grafis layaknya kamera berada di posisi atas marker di dunia nyata.

Hasil kinerja dari Augmented Reality sangat bergantung pada pencahayaan dan fokus kamera. Marker yang digunakan biasanya menggunakan ilustrasi berwarna hitam tebal di bagian pinggiran sekitar gambar berwarna putih, hal ini bertujuan untuk mempermudah komputer mengenali nilai referensi yang ada pada marker tersebut.

Sistem markerless pada Augmented Reality menggunakan kombinasi dari beberapa alat elektronik seperti: accelerometer, kompas, data lokasi (GPS), 3D object tracking, dan motion tracking untuk menentukan posisi pada dunia nyata, dimana sistem ini akan mengarahkan poros mana dari suatu alat yang beroperasi. Data lokasi ini kemudian juga bisa dibandingkan dengan database yang menentukan apa yang dilihat perangkat, dan dengan memungkinkan komputer untuk menampilkan grafis pada layar. Teknologi ini menciptakan 'mobile augmented reality', dengan menggunakan perangkat teknologi seperti smartphone dan tablets.

\subsection{Strategi Pemasaran}

Strategi adalah hal yang menetapkan arah kepada manajemen dalam arti orang tentang sumber daya didalalm bisnis dan tentang untuk membantu menenangkan persaingan didalam pasar (Mulyadi, 2012).

Pemasaran merupakan salah satu fungsi strategi dalam perusahaan dalam menjalankan aktivitas bisnisnya, terutama saat persaingan dalam industri menunjukkan intensitasnya yang semakin tinngi.

Pemasaran merupakan ujung tombak bagi eksistensi perusahaan dalam rangka jangka panjang. Pemasaran yang efektif dapat mempertemukan antara perusahaan dan konsumennya, baik secara langsung maupun melalui perantara. Pemasaran 
merupakan aktivitas perusahaan untuk memperoleh, mengembangkan, dan mempertahankan konsumen, baik konsumen yang sudah ada maupun konsumen baru. Dengan demikian pemasaran yang berhasil identik dengan semakin meningktanya loyalitas konsumen dan tumbuhnya konsumen baru mampu memberikan kontribusi signifikan terhadap perusahaan.

Pemasaran (marketing) berasal dari kata market (pasar). Secara sederhana, pasar dapat dipahami sebagai tempat sekelompok penjual dan pembeli bertemu untuk melaksanakan kegiatan transaksi tukar menukar barang.

Stanton (2005) menyatakan bahwa pemasaran adalah system total dari kegiatan bisnis yang dirancang untuk merencanakan, menentukan harga, mempromosikan, dan mendistribusikan barang-barang yang memuaskan keinginan dan jasa, baik kepada konsumen saat ini maupun konsumen potensial.

Terdapat beberapa pendapat tentang pemasaran anatara lain :

a. Pemasaran dianggap sebagai proses perencanaan konsep, harga, promosi, dan pendistribusian ide-ide barang dan jasa untuk menciptakan pertukaran yang memuaskan individu dan tujuan organisasi.

b. Pemsaran merupakan fungsi organisasi dan satu set proses untuk menciptakan, mengkomunikasikan dan menyampaikan nilai kepada konsumen dan membangun hubungan konsumen yang memberikan keuntungan bagi organisasi dan pihak-pihak yang berkepentingan terhadap organisasi.

c. Pemasaran merupakan sekumpulan aktivitas dan fungsi manajemen yang di dalamnya terdapat bisnis dan organisasi lainnya.

Strategi pemasaran adalah himpunan asas yang secara tepat, konsisten, dan layak dilaksanakan oleh perusahaan guna mencapai sasaran pasar yang dituju (target market) dalam jangka panjang dan tujuan perusahaan jangka panjang (objectives), dalam situasi persaingan tertentu. Untuk itu kegiatan dalam pemasaran industri bisnis harus direncanakan sesuai strategi yang optimal (Wijaya, 2013).

Menurut Assauri (2011) bahwa strategi pemasaran adalah rencana yang menyeluruh, terpadu dan menyatu di bidang pemasaran, yang memberikan panduan tentang kegiatan yang akan dijalankan untuk dapat tercapainya tujuan pemasaran suatu perusahaan. Dengan kata lain, strategi pemasaran adalah serangkaian tujuan dan sasaran, kebijakan dan aturan yang memberi arah kepada usaha-usaha pemasaran perusahaan dari waktu ke waktu, pada masing-masing tanggapan perusahaan dalam menghadapi lingkungan dan keadaan persaingan yang selalu berubah.

Dalam bentuk situasi strategi pemasaran ini terdapat strategi acuan pemasaran, yang menetapkan komposisi yang terbaik dari beberapa hal komponen pemasaran, untuk dapat mencapai sasaran pasar yang dituju, dan sekaligus mencapai tujuan dan sasaran perusahaan. Adapun bentuk strategi pemasaran yaitu, Strategi Produk, strategi harga, strategi, penyaluran atau distribusi, strategi promosi, dan strategi pemasaran.
Pemasaran adalah sebagai suatu proses sosial dan managerial yang membuat individu dan kelompok memperoleh apa yang mereka butuhkan dan inginkan lewat penciptaan dan pertukaran timbal balik produk dan nilai dengan orang lain. Dalam orientasi pasar perlu pengetahuan mengenai jenis pasar yang akan dimasuki, termasuk di dalam karakteristiknya. Dengan demikian dapat diketahui arah yang jelas mengenai orientasi pasar dari produk yang dihasilkan. Adapun orientasi pasar yang dimaksud untuk produk industri kerajinan logam adalah pasar dalam negeri/domestik dan pasar ekspor atau luar negeri. Menurut Kotler dan Amstrong (2012) bahwa orientasi dalam manajemen pemasaran meliputi :

1. Konsep Produksi

Konsep produksi merupakan konsep filosofi tertua yang memandu penjualan. Menyatakan bahwa konsumen akan menyukai produk yang tersedia dan harga yang terjangkau. Dengan konsep ini maka manajemen harus berfokus kepada peningkatan efisiensi produksi dan distribusi. Konsep produksi masih merupaka filosofi yang bermanfaat dalam beberapa situasi.

2. Konsep Produk

Konsumen menyukai produk yang menawarkan kualitas, kinerja, fitur inovatif yang terbaik. Berdasarkan konsep ini, strategi pemasaran berfokus pada perbaikan produk yang berkelanjutan.

3. Konsep Penjualan

Banyak perusahaan mengikuti konsep penjualan (selling concept) yang menyatakan bahwa konsumen tidak akan membeli produk perusahaan kecuali jika produk itu dijual dalam skala penjualan dan usaha promosi besar. Konsep ini biasanya dipraktekkan pada barang yang tidak dicari. Barang barang yang tidak terpikir akan dibeli oleh konsumen dalam keadaan normal, seperti asuransi atau donor darah. Industri-industri ini harus melacak prospek dan menjual produk berdasarkan manfaat produk.

\section{Konsep Pemasaran}

Pencapaian tujuan organisasi tergantung pada pengetahuan akan kebutuhan dan keinginan target pasar dan memberikan kepuasan yang diinginkan dengan lebih baik dari pada pesaing. Dengan konsep ini, fokus dan nilai pelanggan adalah jalan menuju penjualan dan keuntungan. Filosofinya yaitu "membuat dan menjual" yang berpusat pada produk. Konsep pemasaran adalah filosofi "merasakan dan merespon" yang berpusat pada pelanggan. Konsep ini memandang pemasaran bukan sebagai kegiatan berburu tetapi sebagai kegiatan berkebun. Pekerjaan yang dilakukan bukanlah menemukan pelanggan yang tepat buat produk anda tapi menemukan produk yang tepat bagi pelanggan.

5. Konsep Pemasaran Berorientasi Masyarakat

Konsep pemasaran berwawasan sosial mempertanyakan apakah konsep pemasaran murni sudah memeperhatikan kemungkinan konflik antara keinginan jangka pendek dengan konsumen dan kesejahteraan jangka panjang konsumen. Apakah perusahaan yang mampu memuaskan kebutuhan dan keinginan saat ini dari target pasar selalu melakukan terbaik bagi konsumen dalam jangka panjang? Konsep pemasaran berwawasan sosial menyatakan bahwa strategi pemasaran harus dapat memberikan nilai bagi pelanggan dalam cara mempertahankan atau meningkatkan kesejahteraan konsumen dan masyarakat. 


\subsection{Virtual Button Vuforia}

Virtual Button menyediakan sebuah mekanisme yang berguna untuk membuat interaksi antar pengguna dengan target marker menjadi lebih interaktif. Ketika kamera aktif, maka button akan terbentuk dan akan ditangani dalam sistem oleh event trigger 'OnButtonPressed' dan 'OnButtonReleased'. Ketika membuat sebuah virtual button, ukuran dan penempatan menjadi hal yang harus diperhitungkan dengan bijak agar pengguna nyaman. Ada beberapa faktor yang akan mempengaruhi tanggapan dari Virtual Button :

1. Panjang dan lebarnya ukuran Virtual Button

2. Area target Virtual Button

3. Penempatan tombol yang berkaitan dengan perbatasan gambar, dan tombol lain pada target

4. Area tombol harus memiliki kontras dan detail yang tinggi sehingga mudah diaktifkan.

Kotak yang akan ditetapkan untuk area tombol virtual harus sama dengan atau lebih besar dari 10\% dari target marker keseluruhan. Buttons event akan terpanggil ketika pengguna menutupi area yang menjadi virtual button dalam tampilan kamera. Karena alasan ini, button harus berukuran tepat agar tindakan yang ditanggapi akan benar. Misalnya, button yang akan dipicu oleh jari pengguna harus lebih kecil dari yang dipicu oleh seluruh tangan mereka.

Virtual Buttons mendeteksi ketikan ada object yang menutupi target marker pada hasil kamera. Agar virtual button dapat berjalan baik maka button harus ditempatkan pada area yang memiliki banyak titik agar dapat terpanggil oleh event trigger OnButtonPressed.

Dalam unity, fungsi virtual button dapat ditambahkan ke sebuah mesh melalui script Virtual Button Behaviour atau dapat disalin dari sample Virtual Button Game Objects.

Virtual button terbentuk dari definisi file Dataset Configuration $X M L$ sebagai sebuah property dari image target atau dengan cara adding dan destroying Virtual Button pada aplikasi run time melalui sebah set dari well-defined APIs. Virtual button dapat didemonstrasikan pada target konfigurasi Wood.xml pada native core samples.

\subsection{Gambang Kromong}

Orkes Gambang Kromong adalah sebuah perpaduan seni musik antara unsur budaya Indonesia khususnya betawi dengan Cina. Unsur Cina yang tampak dalam Gambang Kromong ini berasal dari alat musik gesek seperti: Tehyan, KongAhyan, dan Sukong, sedangkan Unsur budaya Indonesia dapat terlihat pada alat musik seperti: gambang, kromong, gendang, kecrek, dan gong. Perpaduan kedua unsur kebudayaan ini terlihat juga pada lagulagu yang dibawakan. Lagu-lagu yang dibawakan pun berasal dari masing-masing kedua budaya, lagu yang memiliki nuansa betawi antara lain Jali-jali, Surilang, Persi, Balo-balo, Lenggang Kangkung, Ondel-ondel, Gelatik, Ngungkuk dan sebagainya, Disamping itu lagu-lagu yang memiliki nuansa Cina seperti Kong Jilok, Sipatomo, Phe Pantaw, Citnos, Macuntay, Gutaypan dan sebagainya. Sebutan yang digunakan pada tangga nadanya pun berasal dari Bahasa Cina yaitu: Syang atau Hsyang, Ceh atau Tse, Kong, Oh, atau Ho, Uh Lio atau Liu dan Suh (Ruchiat, 2000).

Menurut (Gufron, 2020) sesuai dengan namanya, kesenian gambang kromong menggunakan dua buah alat musik utama berupa gambang dan seperangkat kromong. Keduanya selalu disertai oleh instrumen atau alat musik lain sebagai pelengkap, yaitu: su-kong, teh-hian, kong-a-hian, bangsing (seruling), gong, gendang, kecrek (pan), dan ningnong (sio-lo). Selain instrumen tadi, Kwa (2013) mencatat ada lima buah instrumen yang sekarang sudah tidak dimainkan lagi, yaitu ji-hian (instrumen gesek berdawai dua), ho-sian (instrumen gesek berdawai dua), sam-hian (instrumen gesek berdawai tiga), gweh-khim (semacam gitar berbentuk bulat berdawai dua), dan juanto (semacam terompet berlubang tujuh buah). Nada musiknya hanya memakai lima buah nada (pentatonis) yang mempunyai nama dalam bahasa Tionghoa, yakni: liuh = sol (g), $\mathrm{u}=$ la (a), siang = do (c), che = re (d), dan kong $=$ mi (e). Tidak ada nada $\mathrm{fa}=\mathrm{f}$ dan $\mathrm{si}=\mathrm{b}$ seperti dalam musik diatonis khas Barat. Larasnya pun selendro khas Tionghoa sehingga biasa disebut selendro cina atau selendro mandalungan. Berikut adalah beberapa alat music gambang kromong :

\section{a. Gambang}

Bentuk resonator gambang menyerupai sebuah perahu dengan bagian atas dipasang bilah-bilah kayu manggarawan, suangking, atau huru batu berbentuk empat persegi panjang. Jumlah bilahnya ada 18 buah dan dibagi dalam dua gembyang (oktaf) dengan nada terendah adalah liuh (a) dan nada tertinggi siang (c). Bilah gambang berukuran panjang antara 29-58 centimeter dan "dikunci" menggunakan paku pada bagian atas resonator agar tidak goyah. Cara memainkannya dengan dipukul menggunakan dua buah kayu sepanjang 30-35 centimeter berujung bulat berlapis kain dalam dua tabuham, yaitu dilagu (menurut lagu) dan dicaruk atau dikotek.

\section{b. Kromong}

Bentuk kromong mirip seperti bonang, yaitu kumpulan 10 buah gong "pecon" terbuat dari perunggu atau kuningan yang disusun dua baris dalam sebuah rak kayu. Di dalam rak terdapat kotakkotak kecil untuk menaruh pecon dengan bagian bawah dipasang tali penyangga. Tiap baris berisi lima buah gong dengan nada siang-liuh-u-kong-che pada baris pertama (luar) dan nada chekong-siang-liuh-u pada baris kedua (dalam). Kromong dibunyikan secara berbarengan antara baris luar dan dalam menggunakan dua buah kayu lonjong dengan ujung berbalut kain atau benang dalam tiga tabuhan: dilagu (menurut lagu), dikemprang/digembyang, dan Dicaruk/dikotek/diracik.

\section{c. Kong-a-hian, Teh hian, dan Sukong}

Kong-a-hian, Teh-hian, dan Su-kong mempunyai bentuk sama, hanya ukuran resonator dan gagangnya yang berbeda. Ukuran paling kecil adalah kong-a-hian bernada liuh (g) dan che (d), sedang teh-hian bernada siang (e) dan liuh (g), serta terbesar disebut su-kong bernada su (a) dan kong (e). Ketiga alat musik gesek berdawai dua tersebut terdiri atas resonator (wadah gema) dari tempurung kelapa yang dibelah lalu dilapis kulit tipis, tiang kayu berbentuk bulat panjang, dan purilan atau alat penegang dawai. Kong-a-hian, Teh-hian, dan Su-kong adalah instrumen 
pembawa melodi yang dimainkan dengan cara digesek menggunakan tongkat bersenar plastik (kenur).

\section{d. Gong dan Kempul}

Gong dan kempul terbuat dari kuningan atau perunggu berbentuk lingkaran yang bagian tengahnya menonjol (kenop). Gong berukuran sekitar 85 centimeter berfungsi sebagai penentu irama dasar, sementara kempul berukuran sekitar 45 centimeter berfungsi sebagai pewatas ritme melodi. Oleh karena ukuran gong dan kempul yang relatif besar tersebut, maka umumnya digantung pada sebuah gawangan kayu. Caranya adalah dengan melubangi sisinya sebagai tempat mengikat tali untuk digantungkan pada gawangan kayu berukir motif bunga, sulur dan ular naga setinggi satu meter. Gong dan kempul dibunyikan dengan cara dipukul dari samping pada bagian kenop menggunakan tongkat kayu berujung bulat berlapis kain.

\section{e. Gong Enam}

Sesuai dengan namanya, gong enam terdiri dari enam buah gong berukuran kecil yang digantung pada gawangan kayu dengan susunan nada: $3,1,6,2,1,5$.

\section{f. Kecrek (pan)}

Kecrek atau pan berbentuk dari dua hingga empat lempengan logam tipis (besi, kuningan, perunggu) yang disusun diatas sebuah papan kayu. Alat yang berfungsi sebagai pengatur irama dan untuk menimbulkan efek bunyi tertentu ini dimainkan dengan cara dipukul menggunakan palu khusus atau tongkat kayu pendek hingga menghasilkan bunyi crek-crek-crek.

\section{g. Ningnong}

Ningnong berbentuk dua buah piringan logam perunggu atau kuningan berdiameter sekitar 10 centimeter yang ditempatkan pada sebuah bingkai kayu bertangkai satu. Ningnong dibunyikan dengan cara dipukul menggunakan tongkat besi kecil secara bergantian dari kiri ke kanan atau sebaliknya (teknik pitet), sebagai pengatur irama.

\section{h. Gendang}

Gendang atau kendang terbuat dari kayu berbentuk silinder berongga yang kembung di bagian tengahnya. Pada kedua pangkal gendang berbentuk lingkaran ditutup dengan kulit kambing atau kerbau yang tidak sama besarnya. Bentuk gendang semacam ini biasa disebut sebagai kerucut pepet dan berfungsi sebagai instrumen pengatur irama. Dalam setiap pementasan umumnya terdapat sebuah kerucut pepet dan satu atau dua buah gendang kecil yang disebut ketipung, tepak, tipluk atau kulanter. Kerucut pepet ditempatkan pada dudukan kayu silang kecil di depan, sedangkan ketipung berada di samping kiri atau di pangkuan pemain.

Gambang kromong mempunyai nilai-nilai yang dapat dijadikan sebagai acuan dalam kehidupan bermasyarakat pendukungnya. Nilai-nilai itu meliputi ketekunan, kesabaran, dan kerja keras, kerja sama, kekompakan dan kreatifias. Nilai ketekunan, kesabaran, dan kerja keras tercemin dalam penguasaan alat musik yang dimainkan. Untuk menjadi panjak yang mahir tentu diperlukan kesabaran, ketekunan dan kerja keras. Tanpa itu mustahil seseorang dapat menunjukkan kehebatannya ketika sedang pentas. Bahkan, bisa saja mengganggu jalannya pertunjukkan dan menjadi bahan cemoohan dan tertawaan penonton. Nilai kerja sama tercemin dalam proses pementasan gambang kromong itu sendiri. Sebagai sebuah ensemble tentu memerlukan kerja sama antar pemain atau antar panjak agar pementasan beralan dengan lancar. Nilai kekompakan dan ketertiban tercermin pada bagian atas, diawal munculnya peralatan musik masih bersifat tradisional bernada pentatonis. Namun seiring waktu, penggunaan alat-alat musik modern juga ikut dimainkan sehingga menimbulkan bunyi yang lebih dinamis. Ini artinya, para panjak tidak hanya puas dengan apa yang selama ini dimainkan. Ada proses kreatifitas tertentu untuk memadukan peralatan musik tradisional dengan modern sehingga musik gambang kromong lebih berwarna.

\subsection{Android Operating System}

Android adalah sebuah sistem operasi untuk perangkat ponsel yang merupakan versi modifikasi dari Linux. Awal mulanya dikembangkan oleh startup dengan nama yang sama seperti sistem operasinya yaitu Android Inc. Pada tahun 2005, agar bisa memasuki dunia pasar ponsel, maka Google membeli Android Inc dan mengambil alih hasil pengembangan beserta tim pengembangnya.

Google menginginkan Android OS dapat digunakan banyak pengguna secara gratis dan dapat dikelola terbuka, sehingga Android merilis hampir seluruh kode dibawah lisensi open souce Apcahe. Maka siapapun yang ingin menggunakan Android juga bisa mengunduh keseluruhan source code Android. (DiMarzio, 2017)

Android selalu mengembangkan sistem operasinya sehingga telah tercipta banyak versi dengan keunggulannya. Berikut adalah perkembangan versi Android dimulai dari awal tercipta sampai saat ini (Raphael, 2020).

\section{KONSEP PERANCANGAN}

Penelitian ini menggunakan metode kualitatif, dengan menggunakan 4 cara untuk mengumpulkan data, diantara yaitu:

\section{Observasi}

Observasi yang dilakukan dalam penelitian ini yaitu pengamatan yang dilakukan di kampung Betawi Setu Babakan. Pengamatn yang dilakukan terhadap objek yang diteliti yaitu kesenian Gambang Kromong

\section{Wawancara}

Peneliti melakukan wawancara dengan nara sumber (warga asli Betawi) untuk memperoleh informasi, pendapat, gagasan dan cara pandang. Hal ini sangat perlu dilakukan untuk memperoleh data yang tepat dari sumbernya.

3. Studi Literatur

Peneliti melakukan pencarian terhadap berbagai sumber tulisan seperti buku, majalah, artikel, jurnal ilmiah, serta laporan-laporan penelitian yang terkait dengan hal yang sedang dikaji.

4. Kuesioner Online

Tahap terakhir peneliti memberikan kuesioner online kepada masyarakat untuk mengetahui tanggapan serta komentar dari masyarakat terhadap penggunaan aplikasi Augmented Reality 
sebagai strategi dalam memasarkan kesenian Gambang Kromong.

Pembutatan aplikasi ini membutuhkan software dan hardware. Software untuk mendukung dalam membuat desain, pengolahan kata, dan pembuatan aplikasi, sedangkan untuk hardware membutuhkan computer dengan spesifikasi khusus untuk dapat membuat aplikasi Augmented Reality dan juga smartphone dengan spesifikasi tertentu.

Proses pembuatan aplikasi Augmented Reality untuk memasarkan kesenian Gambang Kromong pada Android melalui 3 tahap, yaitu

1. Tahap pra produksi yang dilaksanakan sebelum pembuatan karya.

2. Tahap produksi yaitu tahap untuk memulai pembuatan karya.

3. Tahap pasca produksi yaitu pengujian karya yang telah selesai dibuat. Berikut adalah gambaran alur kerja dalam pembuatan karya ini ditunjukkan pada gambar 1.

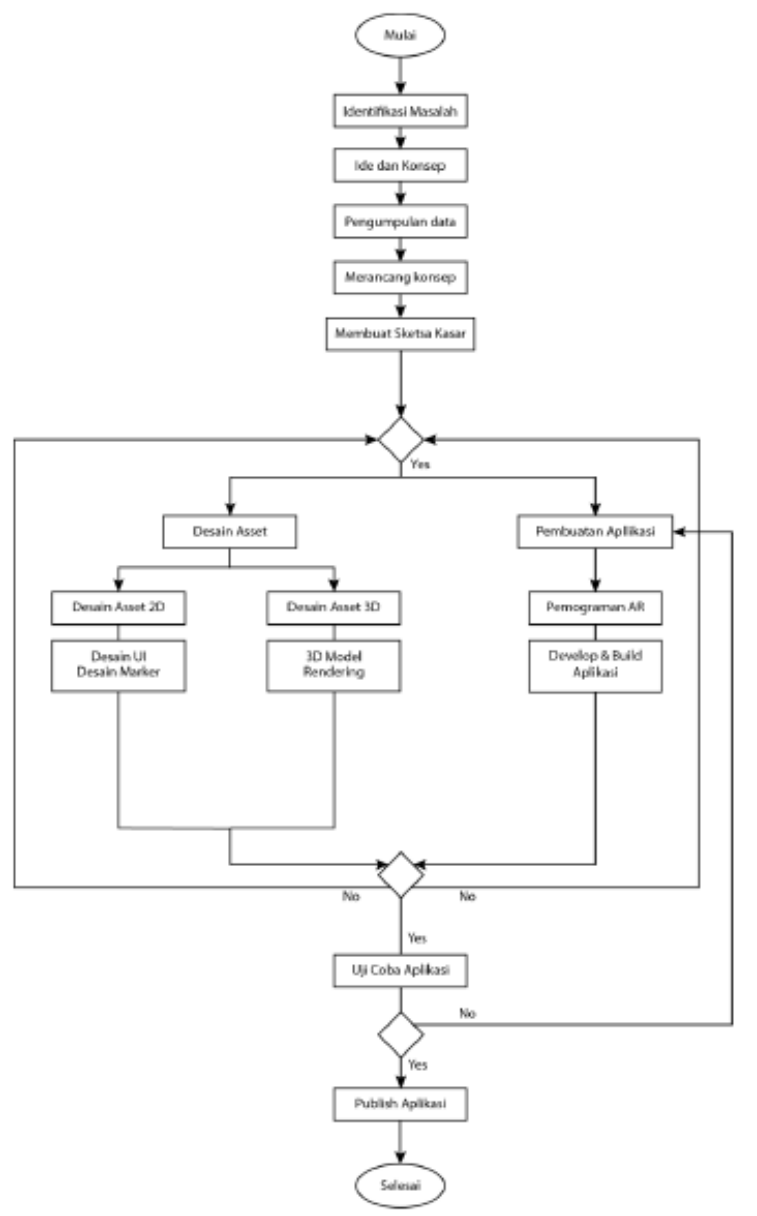

Gambar 1. Flowchart Proses Produksi

Perancangan sistem menggunakan Unified Modeling Language (UML) yang bertujuan untuk memperjelas aplikasi yang akan dibuat, didalamnya terdapat diagram seperti Use Case Diagram, Activity Diagram, dan Class Diagram yang memperjelas bentuk alur sistem aplikasi. Dalam pembuatan User Interafce dibutuhkan rancangan/struktur terlebih dahulu sebagai gambaran. Berikut adalah gambaran struktur menu yang ditunjukkan pada gambar :

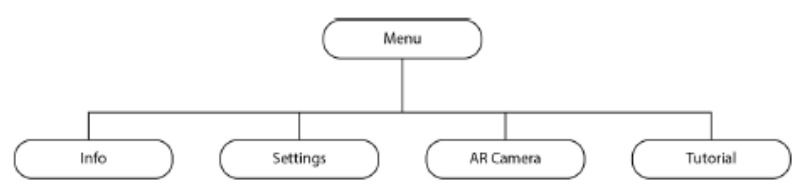

Gambar 2. Struktur Menu

Penggunaan booklet dengan ukuran B5 yang berisikan target marker sebagai media scan agar dapat memudahkan pengguna. Sedangkan rancangan tata letak konten tutorial menggunakan aplikasi pada halaman tutorial booklet.

Proses Perancangan 3D Modeling alat musik Gambang Kromong dimulai dengan membuat model 3D dari masing-masing alat musik menggunakan software blender $3 D$ versi 2.28 . Sebelum memulai pembuatan peneliti sudah memiliki beberapa referensi bentuk model dari setiap alat musik agar objek yang dihasilkan sesuai. Pembuatan model serta texturing selanjutnya akan diexport menjadi FBX agar dapat diaplikasikan.

Rancangan pengujian dilakukan untuk mengetahui kategori hasil terbaik sehingga perlu dilakukan uji coba pada aplikasi. Aspek yang diuji pada aplikasi Augmented Reality untuk memasarkan kesenian Gambang Kromong yaitu berdasarkan faktor internal seperti perangkat yang digunakan, serta faktor eksternal seperti :

a. kondisi cahaya, adapun uji coba cahaya yang dilakukan meliputi keadaan sangat terang, terang, redup, gelap dan flashlight.

b. jarak kamera, adapun uji coba jarak marker terdiri dari $(50,40,30,10,5) \mathrm{cm}$

c. sudut kemiringan kamera, adapun uji coba sudut kemiringan terdiri dari $(90,60,45,30,0)$ derajat.

Sedangkan pelaksanaan uji coba pada Virtual Button berdasarkan sensitifitas.

\section{HASIL DAN PEMBAHASAN}

Kesenian Gambang Kromong yang merupakan perpaduan musik unsur budaya Tionghoa dan Betawi yang masih memiliki regenerasi pemain, penanggap serta penikmat setianya, namun dalam jumlah yang tidak terlalu banyak. Bagi penanggap, gambang kromong dapat dijadikan sebagai sarana hiburan untuk hajatan. Alasan memilih Gambang Kromong karena hobi, untuk menarik perhatian undangan agar mau datang ke hajatan, serta karena tradisi dalam hajatan tersebut memerlukan gambang kromong sebagai musik pengiringnya. Bagi penonton atau penikmatnya kesenian gambang kromong hanya dijadikan sebagai sarana hiburan. Penyebab utama seseorang mau menonton dan mendengarkan alunan musik gambang kromong adalah karena faktor asal usul kesuku bangsaannya. Dalam hal ini, seseorang senang menonton, mendengar, dan menyanyikan lagu gambang kromong dengan maksud untuk menunjukkan identitasnya sebagai orang Melayu-Betawi.

Hasil wawancara dengan beberapa seniman perihal alasan mereka tetap eksis dalam dunia kesenian gambang romong yaitu:

(a) Memainkan Gambang Kromong berarti ikut melestarikan kebudayaan Betawi. 
(b) Bangga mampu memainkan satu atau lebih alat musik Gambang Kromong

(c) Meningkatkan bakat dan menambah pengetahuan,

(d) Menghibur masyarakat

(e) Menjalin silaturahmi pemain, pimpinan, dan penonton

(f) Sebagai mata pencaharian untuk memenuhi kebutuhan hidup sehari-hari.

Pentingnya memasarkan kesenian gambang kromong untuk membantu pelestarian kesenian Betawi dengan cara yang menarik dan efisien, serta sebagai media edukasi kepada masyarakat.

Aplikasi Augmented Reality pada kesenian Gambang Kromong menyediakan bentuk modeling 3 Dimensi dari masing-masing alat musik serta akan mengeluarkan bunyi suara dari alat musik tersebut. Untuk target marker akan disediakan sebuah booklet berisikan tentang Gambang Kromong.

Terdapat tahap pengujian pada aplikasi Augmented Reality untuk kesenian Gambang Kromong berdasarkan variasi kondisi. Berikut adalah beberapa kondisi yang akan diuji cobakan saat Augmented Reality berjalan, yaitu :

1. Variasi Sudut Kemiringan dilakukan uji coba untuk mengetahui kinerja Augmented Reality dari berbagai perspektif. Adapun uji coba sudut kemiringan terdiri dari $(90,60,45,30,0)$ derajat.

2. Variasi Jarak dilakukan uji coba untuk membuat kesimpulan mengenai jarak yang direkomendasi kepada pengguna. Adapun uji coba jarak marker terdiri dari $(50,40,30,10,5) \mathrm{cm}$.

3. Variasi Keadaan Cahaya dilakukan uji coba untuk mengetahui cahaya terbaik dalam menggunakan aplikasi Augmented Reality. Adapun uji coba cahaya yang dilakukan meliputi keadaan sangat terang, terang, redup, gelap dan flashlight.

Selain itu terdapat pengujian pada virtual button untuk mengetahui kelemahan dan kelebihan dari tata letak serta fitur dari virtual button. Cara yang digunakan adalah dengan meletakkan tangan diatas target marker yang sudah ditandai virtual button.

Berdasarkan hasil uji aplikasi Augmented Reality Gambang Kromong dapat dijalankan dengan smartphone berspesifikasi minimal RAM 2GB, sistem operasi Android Marshmallow dan kamera belakang 13MP. Disarankan untuk memperoleh hasil yang terbaik menggunakan smartphone dengan spesifikasi RAM 3GB dengan sistem operasi Android 10. Pengenalan marker terbaik saat melakukan pemindaian terdapat pada jarak 10 sampai $50 \mathrm{~cm}$ dan sudut $45^{\circ}$ sampai $90^{\circ}$ dengan cahaya terang untuk hasil maksimal.

Pengisian kuesioner online terhadap aplikasi Augmented Reality dalam memasarkan Gambang Kromong dilakukan kepada 200 responden yang bedomisili di Jabodetabek. Adapun karakteristik responden berdasarkan usia, jenis kelamin, domisi, pekerjaan, serta tingkat pendidikan.

Terdapat beberapa pertanyaan tentang pengetahuan terhadap kesenian Betawi Gambang Kromong dan sistem aplikasi Augmented Reality pada smartphone pengguna. Adapun hasil dari kuesioner setelah responden menggunakan aplikasi
Augmented Reality dalam memasarkan Gambang Kromong yaitu 150 responden (75\%) menjadi lebih tahu setelah mendengarkan suara instrument Gambang Kromong dengan aplikasi Augmented Reality, terdapat 130 responden (65\%) lebih mengenal kesenian Betawi Gambang Kromong setelah menggunakan apliasi Augmented Reality, 105 responden (52,5\%) menjadi mengetahui alat musik dalam instrument Gambang Kromong, 185 responden (92,5\%) menyatakan aplikasi Augmented Reality membantu responden dalam mengenal Gambang Kromong, 165 responden $(82,5 \%)$ menyatakan aplikasi berjalan dengan baik pada smartphone user, 185 responden $(92,5 \%)$ menyatakan bahwa tidak ada kendala pada smartphone saat menggunakan aplikasi Augmented Reality, 195 responden (97,5\%) memahami cara menggunakan aplikasi tersebut, dan seluruh responden menyatakan aplikasi Augmented Reality dapat berjalan dengan baik.

Dengan demikian aplikasi ini dapat dinyatakan bermanfaat dan juga user friendly. Aplikasi ini dapat digunakan untuk memasarkan kesenian Gambang Kromong sehingga kesadaran masyarakat bertambah terhadap kesenian Gambang Kromong dan meningkatkan rasa cinta terhadap kesenian dan kebudayaan Betawi.

\section{KESIMPULAN DAN SARAN}

Penggunaan aplikasi Augmented Reality dapat digunakan untuk memasarkan Kesenian Gambang Kromong. Aplikasi ini sangat membantu dalam meningkatkan wawasan dan kesadaran masyarakat terhadap kesenian Gambang Kromong sehingga meningkatkan rasa cinta terhadap kesenian dan kebudayaan Betawi.

Adapun saran untuk penelitian selanjutnya yaitu dapat menambahkan informasi mengenai organisasi yang masih memainkan atau yang menyelenggarakan pentas budaya Betawi Gambang Kromong. Selain itu juga bisa ditambahkan video animasi interaktif tentang Gambang Kromong, serta 3D model alat musik yang bisa dimainkan.

\section{DAFTAR PUSTAKA}

[1] Yustafa and Leski, "Strategi Pengembangan Perkampungan Budaya Betawi Setu Babakan Sebagai Daya Tarik Wisata Budaya," Universitas Gaja Mada, 2015.

[2] Suswandari, "Pemahaman Sejarah, Budaya Dan Kearifan Lokal Etnik Betawi Pada Guru Sekolah Dasar Di Wilayah DKI Jakarta," Prosiding Kolokium Doktor Dan Seminar Hasil Penelitian Hibah, 2016.

[3] P. Mealy, Virtual \& Augmented Reality for Dummies, New Jersey: Paul Mealy, 2018.

[4] P. Mealy, Virtual \& Augmented Reality, Hoboken, New Jersey, Canada: John Wiley \& Sons, Inc., 2018. 
[5] Kotler and Armstrong, Principles of Marketing, New Jersey: Prentice Hall, 2012.

[6] Kotler and Keller, Marketing Management, 14th Edition, United States of America: Pearson, 2012.

[7] M. Kesim and Y. Ozarslan, "Augmented Reality in Education: Current Technologies and The Potential for Education," Social and Behavioral Sciences, pp. 297-302, 2012.

[8] P. P. J and H. D. J, A Preface to Marketing Management, Boston : McGraw-Hill, 2003.

[9] S. Intyaswono, "Strategi Komunikasi Pemasaran Dinas Kebudayaan Dan Pariwisata Kabupaten Tana Toraja Dalam Meningkatkan Jumlah Kunjungan Wistawan Di Tana Toraja," Ilmu Komunikasi Universitas Hasanuddin , 2016.

[10] S. Gama, "Strategi Komunikasi Pemasaran Dinas Kebudayaan Dan Pariwisata Kota Jakarta Dalam Meningkatkan Jumlah Kunjungan Wisatawan Di Kampung Budaya (Kampung Setu Babakan Dan Kampung Pecinan Glodok).," Universitas Islam Indonesia, 2019.

[11] S. Feiner, Interviewee, Augmented reality in 2011, is it still a long way off? AR \& VR News.. [Interview]. 2011.

[12] A. Ariesta, " Peran Agensi Budaya dan Praktik Multikulturalisme Di Perkampungan Budaya Betawi," Tantangan Gerakan Nasional , 2016.

[13] Riyanto, T, "Menjaga Eksistensi Gambang Kromong," Berita Jakarta, Jakarta, 2017.

[14] D. Mulyadi, "Analisis Strategi Pemasaran jasa Lembaga Non Bank Pada PT Oto Multiartha Karawang," Jurnal Manajemen, Vol. 09 No. 2 , pp. 590-591, 2012.

[15] I. Wijaya and S. S. Iriani, "Pengaruh Citra Merek Terhadap Loyalitas Konsumen," Jurnal Ilmu Manajemen, Vol. 1 No.3, p. 911, 2013.

[16] S. Assauri, Manajemen Pemasaran Dasar Konsep dan Strategi, Jakarta: PT RajaGrafindo Persada, 2011.

[17] S. Assauri, Manajemen Pemasaran Dasar Konsep dan Strategi, Jakarta: PT Raja Grafindo Persada, 2002.

[18] W. J. Stanton, Prinsip Pemasaran, Jakarta: Erlangga, 2005. 